\title{
Politička ekonomija i kritika teorije društvenog ugovora u Hegelovoj Filozofiji prava
}

\author{
DOMAGOJ VUJEVA
}

Fakultet političkih znanosti, Sveučilište u Zagrebu

\begin{abstract}
Sažetak
Autor tematizira recepciju političke ekonomije u Hegelovoj Filozofiji prava. Ta je recepcija bila presudna za razvoj Hegelove pravno-političke filozofije i njenu zrelu formulaciju, ali je istovremeno njome posredovan i Hegelov odnos prema modernom prirodnom pravu i ugovornoj političkoj teoriji. Oslanjajući se na Strpićeve nalaze, autor pokazuje kako je mjestom realizacije ugovornog modela države Hegel smatrao građansko društvo. Zakonitosti imanentne modernoj tržišnoj ekonomiji, koje je "otkrila" politička ekonomija, prema Hegelovu sudu čine izlišnim ugovornu konstituciju države, ali i predstavljaju unutarnju mjeru kritike ugovorne teorije. To međutim ne znači da Hegel prihvaća model društva klasične političke ekonomije niti njeno razumijevanje odnosa države i društva. On dovodi u pitanje prije svega njenu središnju pretpostavku o sposobnosti tržišta za samoregulaciju, zbog čega smatra nužnom državnu regulaciju tržišta. U posljednjoj analizi pokazuje se kako je "općenitost" građanskog društva utemeljena u "općenitosti” političke države, koja predstavlja viši stupanj ozbiljenja čovjekove slobode.
\end{abstract}

Ključne riječi: Hegel, politička ekonomija, Strpić, društveni ugovor

U Strpićevoj rekonstrukciji klasične političke ekonomije i moderne političke teorije, čiji je cilj istražiti relaciju "robne proizvodnje" i "udruženog rada" u Marxovoj kritici političke ekonomije, posebna je pažnja posvećena Hegelovoj pravno-političkoj filozofiji. Razloge Hegelove važnosti za tako postavljen istraživački problem Strpić sam navodi. Hegel je posljednji veliki predstavnik obje tradicije (prije Marxa, koji provodi kritiku i jedne i druge) i ujedno, uz Ricarda, najraniji i najuspješniji interpret britanskog klasičnog sistema (Strpić, 2017: 342). Njegova je interpretacija "oblik" u kojemu se Marx "po prvi put susreo s britanskim klasicima i njihovom političkom ekonomijom" (ibid.), a u Filozofiji prava izložena teorija “dr- 
žavne zajednice", razvijena "na suprotstavljanju političke države građanskom društvu", poslužila je mladom Marxu kao "gotov predložak za pokušaj kritike političke ekonomije" (ibid.: 95). Marxovo preuzimanje znanstvenih rezultata klasične političke ekonomije preko Hegelove interpretacije i njegove filozofije općenito (kasnije posebice posredstvom Fenomenologije duha i Logike) izvršit će presudan i trajan utjecaj na njegovo razumijevanje britanskih klasika (ibid.: 141)1.

Drugačije međutim od eminentnih pravaca u marksističkoj tradiciji interpretacije Marxa, Strpić, prema vlastitom svjedočenju, Marxovu kritiku političke ekonomije ne vidi ni "kao primjenu Hegelove filozofije na političku ekonomiju (...) niti kao posebnu znanost koja s Hegelom više nema ništa zajedničko" (ibid.: 16). Njega općenito manje zanima u marksizmu često tematiziran odnos Hegel-Marx, iako priznaje da se "zaizvjesno radi o velikom utjecaju" i da se nije ustezao pokazati ga tamo gdje je na njega naišao (ibid.). Ali interpretativno plodnijim i stoga neophodnim se u konačnici - jer "u prvotnom projektu studije takva širina nije bila predviđena" (ibid.: 18) - pokazao drugačiji pristup, koji je i istraživački neizmjerno zahtjevniji. "Naime, i za tumačenje Hegela, među odlučnim klasičnim autorima (izvan kruga klasičnog njemačkog idealizma) također su Hobbes, Locke, Hume, Smith - kao što su prirodno sugovornici u kritici političke ekonomije. A kada po Marxovu samorazumijevanju i nisu ključni, i možda uopće nisu pokazani kao sugovornici, oni su objektivno ipak odlučni jer su formirali paradigmu unutar koje se, ili u odnosu na koju se, u najmanju ruku, htjeli to ili ne, kreću i Marx i Hegel" (ibid.). ${ }^{2}$

1 Što će "uvjetovati i stanovita nerazumijevanja, osobito kad je riječ o Smithu. Jer Marx će neke Smithove tekovine razumjeti najprije preko Hegela, a potom preko Ricarda (koji put, privremeno, i nasuprot Hegelu), a ne u njihovoj genezi iz klasične britanske teorije od Hobbesa nadalje. Stoga će ih dugo, prešutno ili izrijekom, i pripisivati ovoj dvojici ili kritizirati preko njih, da bi tek u Kapitalu ove relacije sustavno zadobivale svoju pravu mjeru" (Strpić, 2017: 141). O načinu na koji se Marx i "u Kapitalu otkrio kao Hegelov učenik" vidi str. 148 Strpićeva rada.

${ }^{2}$ Strpićeva reinterpretacija fundamentalnih tekstova moderne iz perspektive Marxove kritike političke ekonomije već je impozantan istraživački poduhvat. Kao njegov zaseban, sadržajno iznimno važan znanstveni doprinos ovdje bih htio izdvojiti i ukratko razmotriti Strpićevo razmatranje moderne "paradigme" u jedinstvu njene političko-teorijske i političko-ekonomske tradicije. Rodonačelnik je obje tradicije prema Strpićevom tumačenju Hobbes. Njegovo je političko mišljenje s jedne strane ishodište teorije države, koja je kao moderan tip poretka i specifična "građanska zajednica", ili "suverena građanska država", strukturalno i funkcionalno podudarna modernom tržišnom društvu zasnovanom na robnoj proizvodnji i razmjeni te je pravno-politička pretpostavka njegovog povijesnog nastanka i razvoja (Strpić, 2017: 29). Na taj način otkrivaju se ekonomske implikacije pravno-političkih pretpostavki rano-moderne političke teorije (prije svega Hobbesove i Lockeove). Istodobno, rana moderna politička teorija i izravno tematizira neke ekonomske kategorije (rad kao čovjekova prirodna i instrumentalna moć, proizvodnja, bogatstvo, razmjena kod Hobbesa, privatno vlasništvo, rad, novac kod Lockea itd.), kao i njihove socijalne i političke konzekvence, a one su, prema Strpićevu sudu, već u Hobbesovoj "građanskoj 
Hegelova recepcija političke ekonomije izvršila je, izvan svake sumnje, kao što su pokazale brojne interpretacije, odlučujući utjecaj na razvoj njegove političke filozofije kao filozofije objektivnog duha i na njenu konačnu artikulaciju u Filozo-

filozofiji" (više ili manje osviješteno) osnova konstitucije zajednice i princip njene reprodukcije (ibid:: 54). U tako postavljenom interpretativnom okviru kreću se autori britanske političke ekonomije, istražujući ekonomske principe funkcioniranja "građanskog ili trgovinskog društva". Kontinuitet klasične političke ekonomije s ranijom političkom teorijom Strpić uzima kao samorazumljiv, pristajući uz Schumpeterov sud o političkoj ekonomiji kao spoju ranije, britanske političke teorije i poslovnih komentara (ibid.: 62, 113). Izričita ili prešutna polemika koju su s Hobbesom i Lockeom vodili Petty, Hume, Smith i ostali britanski klasici i u kojoj su izborili vlastite pozicije samo potvrđuje taj kontinuitet, kao što jednako tako nema dvojbe da su njihovi uvidi imali transformativan učinak na pravno-politički okvir preuzet od ranije tradicije. No, oni su pripadali istoj "paradigmi” $i$ istraživali su istu "građansku zajednicu", čiji su princip samoreprodukcije otkrili u "zakonitostima" novonastajuće tržišne ekonomije. Pravno-političke kategorije ranije političke teorije politička ekonomija stoga prevodi u jezik ekonomske teorije, što Strpić zorno prikazuje na primjeru odnosa Smitha i Hobbesa. "Hobbesovim kategorijama moći, zajedničke i opće moći [Power, Common Power], kao i njihovu međusobnu odnošenju, u Smithovu djelu korespondiraju kategorije proizvodnje i kupovne moći [productive power, purchasing power], odnosno zajedničke i opće zalihe/stocka [common stock, general stock] - s time da ovaj posljednji preuzima ekonomske funkcije državne, Hobbesove suverene moći [Sovereign Power]" (ibid.: 362). Ali to znači i, obratno, da sada ekonomski principi preko kojih se vrši samoreprodukcija "građanskog društva" (podjela rada, kupovna moć, razmjenska vrijednost itd.) imaju političke implikacije i nužno moraju biti i predmetom istraživanja političke teorije. Nije na koncu naodmet podsjetiti da je Smith u Bogatstvu naroda političku ekonomiju odredio kao granu "znanosti državnika ili zakonodavca" (usp. Smith, 2007: 419). Pettyu, Humeu, Smithu i ostalim britanskim klasicima njihov je kontinuitet s tradicijom političke teorije, koji današnja ekonomska kao i politička znanost često previđa, bio jasan. A bio je očigledan i Hegelu, čija je filozofija prava, u bitnom smislu, sinteza tih dviju tradicija, kako će se pokazati u nastavku ovoga rada. Ne skrivajući točke diskontinuiteta i uvažavajući njihove specifičnosti, Strpićeva studija pokazuje kako se političko-teorijsku i političko-ekonomsku tradiciju moderne može primjereno i smisleno razumjeti jedino ako se obje razmotre iz perspektive jedinstvene moderne paradigme, čije intelektualno nasljeđe stoga treba, u skladu sa Straussovim općim naputkom o istraživanju političkih ideja, interpretativno tretirati ne kao povijest fundamentalno različitih učenja, nego učenja koja daju različite i često protuslovne odgovore na ista fundamentalna pitanja (Strauss, 1988: 56-77). (Znakovito je da pregled povijesti političke filozofije, koji je Strauss uredio zajedno s J. Cropseyem, sadrži poglavlje o A. Smithu, usp. Strauss/Cropsey, 2006: 453-469.) Strpićevom istraživanju interpretativno je srodno proučavanje odnosa politike i ekonomije u moderni britansko-mađarskog političkog teoretičara Istvana Honta. Bilo bi izrazito vrijedno usporediti njihove načine čitanja modernih klasika političkog i političko-ekonomskog mišljenja, ali takva usporedba zaslužuje zasebnu studiju. Ovdje međutim vrijedi izdvojiti Hontovu studiju Politics in Commercial Society. Jean Jacques Rousseau and Adam Smith, u kojoj Hont, nasuprot uvriježenom tumačenju Rousseaua i Smitha kao autora s oprečnim pogledima na politiku i ekonomiju, otkriva bitne sličnosti među njima, predstavljajući ih s uvjerljivim argumentima obojicu kao autore čija su učenja (kao i razlike u njihovim političkim i ekonomskim rješenjima) imala zajednički korijen u razmatranju nastanka, pokretačkih strasti i konstitutivnih principa "trgovinskog 
fiji prava. Upravo poimanje punih implikacija polit-ekonomske analize, a ne samo nastojanje da se preuzmu njezini pojedini nalazi prijelomna je točka koja dijeli Hegelovu ranu političku filozofiju, u bitnome još orijentiranu na klasični političko-teorijski okvir, od zrele formulacije filozofije prava, čiji temelji su postavljeni već u tzv. drugoj jenskoj Realnoj filozofiji iz 1805/1806. No lektira Adama Fergusona, Jamesa Steuarta, Davida Ricarda, a ponajviše Adama Smitha omogućila je Hegelu, povrh toga, i sustavno kritičko suočavanje s tradicijom modernog prirodnog prava, odnosno s u njoj razvijenom teorijom društvenog ugovora, kojoj tradiciji, $u$ Hegelovu samorazumijevanju, barem načelno pripada i njegova filozofijska znanost prava. Krajnji ishod tog suočavanja bit će preuzimanje bitnih principa modernog prirodnog prava na različitim razinama unutrašnje strukture filozofije prava, uz istovremeno odbijanje prirodnopravne izvedbe države putem društvenog ugovora, odnosno odbacivanje, u metodičkom smislu, ideje prirodnog stanja i distinkcije prirodno - građansko stanje.

Iako se Hegel sa škotskim prosvjetiteljstvom upoznao već tijekom studentskih dana u Tübingenu (preko Fergusona i Humea, koje je, vjerojatno, već i ranije čitao) (Waszek, 1988: 101-110), čini se kako je interes za političku ekonomiju razvio za vrijeme boravka u Bernu (1796-1799), kamo odlazi neposredno nakon studija i zapošljava se kao privatni učitelj. Izvjesno je da je ondje kupio i primjerak Smithova Bogatstva naroda na engleskom, iako mu se, po svemu sudeći, nije ozbiljno posvetio sve do preseljenja u Jenu 1802. (ibid.: 112-113). ${ }^{3}$ Političku ekonomiju Hegel počinje sustavno proučavati preko (u Filozofiji prava prešućenoga) Jamesa Steuarta, o čijem kapitalnom djelu Istraživanja o principima političke ekonomije piše komentar, koji je kasnije izgubljen. ${ }^{4}$ Ako je vjerovati Hegelovu biografu Rosenkranzu, koji

društva". U tom smislu Hont nudi čitanje, koje sam naziva “prividno radikalnim", prema kojemu su obojica, "a ne samo Smith, kako se konvencionalno misli - bili teoretičari trgovinskog društva” (Hont, 2015: 2). Hontovo razmatranje dijaloga između Rousseaua i Smitha samo je međutim dio njegovog "šireg promišljanja o politici, prvenstveno u periodu između Thomasa Hobbesa s jedne strane i Karla Marxa s druge i prvenstveno onoga što je podrazumijevalo - povijesno i analitički - promišljanje politike i ekonomije zajedno" (Kapossy/Sonenscher, 2015: xiv). To promišljanje dijelom sadrži već studija o Rousseauu i Smithu, koja te autore dovodi u dijalog s Ciceronom, Hobbesom, Lockeom, Montesquieuom, i drugim klasicima, ali posebno i iscrpno Hontova velika studija Jealousy of Trade. International Competition and the Nation-State in Historical Perspective (2010).

${ }^{3}$ Detaljnu kronologiju Hegelova upoznavanja sa škotskim prosvjetiteljstvom, s jasno naznačenim izvorima izravnog i posrednog utjecaja te usporednom analizom najvažnijih ekonomskih kategorija, donosi studija Norberta Waszeka The Scottish Enlightenment and Hegel's Account of Civil Society (Waszek, 1988). Waszekova knjiga sadrži i pregled nastanka te prikaz najvažnijih ideja škotskog prosvjetiteljstva, kao i kratak pregled recepcije tih ideja u Njemačkoj u drugoj polovici 18. st.

${ }^{4}$ O Steuartovom utjecaju na Hegela vidi Chamley, 1963. i Plant, 1977: 80-86. 
je taj spis još imao pred sobom, Hegel se u njemu "borio protiv onoga što je mrtvo" u Steuartovu merkantilizmu, "nastojeći spasiti ćud [Gemüth] čovjeka u uvjetima konkurencije i mehaničke interakcije rada i trgovine" (Rosenkranz, 1844: 86). ${ }^{5}$ Prema britanskim klasicima međutim, Hegela je odveo njegov interes za ekonomsku empiriju: u Bernu se on bavi fiskalnom politikom gradske oligarhije do najsitnijih detalja, proučava engleske zakone za siromašne (Dickey, 1987: 192), prikuplja podatke iz britanskih novina, šireći tako pogled prema Britaniji, "industrijski i trgovinski najrazvijenijoj zemlji” onoga vremena. "Čini se da je prikupljanje tih empirijskih podataka potaknulo Hegela da potraži analitički okvir kojim bi organizirao "masu detalja"' (Waszek, 1988: 111). Kod škotskih i britanskih klasika on je pronašao uvid u opće principe i "zakonitosti” funkcioniranja modernog tržišnog društva, koji povezuju njemu svojstvene, naizgled nepovezane i slučajne ekonomske fenomene. Taj uvid on preuzima i primjenjuje već u ranim jenskim spisima, u kojima prvi puta, upravo u vrijeme svog sustavnog upoznavanja s političkom ekonomijom, eksplicitno razmatra ekonomske kategorije (izuzmemo li izgubljeni rukopis o Steuartu), nastojeći im pronaći mjesto u svom sustavu praktične filozofije. U Članku o prirodnom pravu iz 1802/1803. on tako ističe da se "fizičke potrebe i užici (...) stav-

${ }^{5}$ Rosenkranzovo tumačenje Hegelova čitanja Steuarta doveo je u pitanje Dickey: "Rosenkranz, koji je zbog vlastitih razloga htio Hegela prikazati kao mislioca liberalnog uvjerenja, smatrao je kako (sad izgubljeni) rukopis, koji je nekoć imao u svom posjedu, pokazuje Hegela kao protivnika 'onoga što je mrtvo' u 'merkantilnom sustavu' koji je Steuart (navodno) podupirao" (Dickey, 1987: 192-193). Rosenkranzova je greška u nerazlikovanju "merkantilnog i neo-merkantilnog aspekta ekonomskog mišljenja kasnog 18. st." (ibid.: 407, b. 81). Oslanjajući se na istraživanja A. Skinnera, Dickey pokazuje kako Steuart nije bio “'neprosvijećeni' sedamnaestostoljetni merkantilist; niti je bio pristalica one vrste 'prosvijećenog despotizma', koji je bio tako blizak fiziokratima (...) Njegova je koncepcija 'državnika' pažljivo osmišljena i uravnotežena” (ibid.: 198). A i neka shvaćanja o bitnim pretpostavkama i obilježjima modernog tržišnog društva Smithu i Steuartu su bila zajednička (ibid.: 197). Još je međutim važnije da ni u okviru njemačke recepcije britanske političke ekonomije njihova učenja nisu doživljavana kao međusobno suprotstavljena. Velika popularnost Steuarta u njemačkim znanstvenim i intelektualnim krugovima - posebice među kameralistima - proizlazila je iz uvjerenja (koje su međutim dijelili i Smithovi njemački sljedbenici) da klasični liberalni model tržišta, teorijski razvijen u Britaniji i primjeren njenim okolnostima, ne može biti naprosto prenesen u Njemačku, bez prilagodbe na njenu (komparativno nerazvijeniju) socio-ekonomsku situaciju, što je zahtijevalo neku vrstu političke kontrole i usmjeravanja ekonomskog razvoja (ibid.: 195-196). "Nijemci su tako od početka bili skloniji pristupiti ekonomiji manje iz perspektive teorije, a više unutar šireg sociološkog i povijesnog okvira (...) Drugim riječima, pitanje nije bilo merkantilizam ili laissez-faire, Steuart ili Smith, nego se radilo o nužnosti novog sporazuma za građansko društvo", prema kojemu je zadaća države bila "upravljati via media između previše regulacije i previše slobode" (ibid.: 196). Zbog svih tih razloga Dickey zaključuje kako je "sasvim moguće, čak i vjerojatno da je Hegel čitao Smitha i Steuarta kao međusobno komplementarne autore, a ne - kako je konvencionalno shvaćanje - kao zagovornike dvije suprotne interpretacije svrha 'političke ekonomije"' (ibid.: 199). 
ljeni za sebe ponovo u totalitet, pokoravaju u svojim beskonačnim prepletenostima jednoj nužnosti i grade sustav opće uzajamne zavisnosti s obzirom na fizičke potrebe i rad te gomilanje za njih, te - kao znanost - sustav takozvane političke ekonomije” (JS, 349). " “Otkriće” općih zakona funkcioniranja modernoga građanskog

${ }^{6}$ Hegelovi spisi citiraju se prema našim prijevodima, ako postoje, pri čemu se korekcija, kad se pokazala potrebnom, vršila prema izvornim tekstovima na njemačkom, koji su također navedeni u popisu literature. Hegelova djela navodit će se u skraćenom obliku: kratica naslova i broj stranice ili paragrafa, npr. Filozofija prava FP, §285.

Hegel već u ranim jenskim spisima sadržajno opisuje specifično moderne ekonomske fenomene - što sugerira sama upotreba ranijim periodima nezamislivog izraza "politička ekonomija". No osnovni je problem, kao što je uvodno napomenuto, što je Hegelov rani jenski sustav koncipiran po uzoru na antičku, točnije Aristotelovu praktičnu filozofiju, što ima bitne posljedice za razumijevanje ekonomskih kategorija i njihov status u poretku zajedničkog života ljudi (Ilting, 1974: 771-772). One su dodijeljene sferi koja je u odnosu na istinsku ćudorednost uvijek shvaćena kao deficijentna (Göhler, 1976: 92), a strukturalno im pripada mjesto koje u Aristotelovoj znanosti o politici zauzima oikos. Tako su u Sustavu ćudorednosti - koji je nastao gotovo u isto vrijeme kad i Članak o prirodnom pravu - teme poput potrebe, rada, oruđa, podjele i specijalizacije rada, suviška, vrijednosti, cijene, novca, trgovine, naposlijetku vlasništva, razmjene i ugovora, razmotrene unutar "prirodne ćudorednosti", zajedno s odnosom spolova, ljubavi, odnosom roditelja prema djeci i brakom (SĆ, 9-31). Čitava sfera "prirodne ćudorednosti" - čija se izgradnja izvanjski odvija prema izrazito formaliziranoj, po uzoru na Schellinga izgrađenoj metodi kombiniranja "potencija" u kojima se naizmjenično supsumiraju zor i pojam, a ne dijalektičkim napredovanjem samih fenomena (Göhler, 1976: 89 i 93) - kulminira u "potenciji" koju čine odnos "gospodstva i sluganstva" te obitelj (vidi i Vujeva, 2015: 44-48). Ta proturječnost između (modernog) sadržaja i (klasičnog) okvira jednako je prisutna u Članku o prirodnom pravu, u kojemu je s jedne strane pojedinac kao privatni vlasnik, ili član "sustava privatnog vlasništva i prava" određen kao opće biće ili građanin u smislu "bourgeois", dok su s druge strane ti isti pojedinci, koji kao građani "u smislu bourgeois" obavljaju ekonomske aktivnosti i stupaju u pravne odnose kao opća bića, svrstani u jedan stalež, i to stalež neslobodnih (JS, 354, vidi i Vujeva, 2009: 168). Klasični okvir, koji u ranim jenskim tekstovima onemogućuje razumijevanje specifično modernog karaktera izloženih ekonomskih kategorija, kao i njihovih implikacija za ustrojstvo zajednice, Hegel će odbaciti najkasnije u tzv. jenskoj Realnoj filozofiji iz 1805/1806. Usporedna analiza tekstova iz ranoga i kasnoga jenskog perioda, koja bi dokazala kako Hegel u Realnoj filozofiji iz 1805/1806. dolazi na stajalište moderne političke teorije, prevazilazi okvire ovoga rada (za takvu analizu vidi Göhler, 1974). Ona bi međutim kao novost Hegelove političke teorije u kasnom jenskom periodu morala uzeti u obzir metodički pomak prema izgradnji sustava imanentnim napredovanjem fenomena i shvaćanjem njegovih institucionalnih formi kao eksplikacija svijesti, odnosno samorazvoja duha (Göhler, 1974: 419-421; Siep, 2014: 204 i 212; Weisser-Lohmann, 2011: 98), a sadržajno prije svega odbacivanje teleološkog pojma prirode (na osnovu kojega je Hegel u ranim jenskim tekstovima "prirodu" odnosno "prirodno stanje" smatrao uzorom za "pravno stanje") (Riedel, 1982: 88-92, 97), kao i njegovo izričito isticanje "individualnosti" kao višeg principa novijeg vremena (JR II, 251). Jedan od pokazatelja transformacije Hegelove političke filozofije vjerojatno je i njegovo povezivanje principa modernog prirodnog prava i političko-ekonomskih kategorija u drugoj jenskoj Realnoj filozofiji (Riedel, 1982: 33 i posebno 127). 
društva Hegel je smatrao najvažnijim dostignućem političke ekonomije, ističući ga i u izričitoj referenci na političku ekonomiju u Filozofiji prava. ${ }^{7}$ Ono će biti presudno i za njegov odnos prema modernom prirodnom pravu. O tome izvanjski svjedoči već Hegelovo isticanje u Članku o prirodnom pravu da je sfera vlasništva i prava, u kojoj čovjek vrijedi kao "ono opće ili kao građanin, u smislu kao bourgeois" (JS, 358), "idealnost" (JS, 350) općosti svojstvene ekonomskim procesima sustava potrebe i rada. No ne radi se samo o prepoznavanju moderne tržišne ekonomije kao "materijalne" osnove modernih (prirodno)pravnih principa, odnosno ovih posljednjih kao pretpostavki funkcioniranja tržišnih procesa, ${ }^{8}$ nego prije svega o Hegelovom (kasnijem) posredovanju prirodnopravne koncepcije društva, točnije ugovornog utemeljenja države s modelom društva klasične političke ekonomije, koje će imati presudne posljedice za strukturu njegove filozofije prava.

O vlastitom odnosu prema modernom prirodnom pravu Hegel najpregnantnije polaže račun u §3. objavljenog teksta Filozofije prava, a još iscrpnije u "Predgovoru" posthumno objavljenih berlinskih predavanja o filozofiji prava iz 1824/1825. Na oba mjesta svoju filozofiju prava svrstava uz moderno prirodno pravo - budući da im je zajedničko ishodište i supstanca sloboda, odnosno izvor prava kao "ono čovjeku i svakom čovjeku unutrašnje vlastito" (PR 1824/1825, 81) - i obje znanosti zajedno postavlja u inicijalnu opreku, za koju, doduše, odmah ističe da ju je potrebno prevladati, s pozitivnom znanošću o državi. Pa ističe kako je "prirodno pravo inače uobičajen naziv za našu znanost" (ibid.: 75). No odmah zatim odbacuje taj naziv kao neprimjeren, zadržavajući ga međutim u podnaslovu Filozofije pra$v a$, uz "znanost o državi”, kao očitovanje iskazane ambicije da svojom filozofijom prava prevlada suprotnost između te dvije velike tradicije europskoga političkog mišljenja. ${ }^{9}$ Kao temeljni razlog odbacivanja naziva "prirodno pravo" Hegel navodi

${ }^{7}$ Koju međutim ondje sada, na tragu njemačkog kameralizma, naziva "ekonomijom države" [Staatsökonomie]. "Ekonomija države (...) je jedna od znanosti koja je, kao na svom tlu, nastala u novije vrijeme. Njen razvoj pokazuje interesantnost kako misao (vidi Smith, Say, Ricardo) iz beskonačnog mnoštva pojedinačnosti, koje su isprva ležale pred njom, iznalazi jednostavne principe stvari, razum, koji je u njima djelotvoran i koji njima upravlja" (FP, §189).

8 Takvu vezu između dvije tradicije Hegel uostalom ne uspostavlja osviješteno u ranim jenskim spisima, nego najranije u prvoj, a posebno u drugoj jenskoj Realnoj filozofiji (usp. Riedel, 1982: 127).

9 Ta ambicija izazvala je, kako upozorava Schmidt, čuđenje prvih recenzenata Filozofije prava. Oni nisu "mogli razumjeti kako on može povezivati dvije inače odvojene discipline "prirodnog prava' i 'znanosti o državi' u podnaslovu knjige Naturrecht und Staatswissenschaft" (Schmidt, 1981: 470). Slično nerazumijevanje izazvalo je njegovo razlikovanje "građanskog društva" i "države" (ibid.). O Hegelovu odnosu prema modernom prirodnom pravu, kao i o njegovu nastojanju da u Filozofiji prava izvrši pomirenje modernog prirodnog prava s pozitivnom znanošću o državi vidi Riedel, 1970: 10-14. 
dvoznačnost izraza "priroda", dvoznačnost koja, kako kaže, "vodi apsolutnoj zabludi" (ibid.: 76). "Priroda", u ovom slučaju "priroda čovjeka", može značiti s jedne strane pojam čovjeka ili ono u njemu umno, ali, s druge strane, i neposrednu stranu njegova bitka, koja obuhvaća njegove žudnje, strasti i sklonosti. U pristupima modernog prirodnog prava ta dva značenja, po Hegelovu sudu, nisu jasno razdvojena, štoviše, u nastojanju da jasno utvrde ono prvo oni se obraćaju posljednjem, odnosno izvode pojam čovjeka u krajnjoj instanci iz čovjekove neposredne prirodnosti. ${ }^{10}$ Priroda je, zaključuje Hegel, nepristrana, ničemu suprotstavljena, dok "sloboda nastupa polemički, ima suprotnosti, a njena prva suprotnost je priroda sama" (ibid.: 79). ${ }^{11}$

Ovdje ne možemo detaljnije slijediti Hegelove primjedbe tradiciji modernog prirodnog prava. No valja istaknuti da Filozofija prava, osim prikazane načelne kritike i terminoloških distinkcija, sadrži i izričite argumente protiv ugovorne konstitucije države. U Hegelovoj kritici ugovorne teorije mogu se, shematski, razlikovati tri razine argumentacije: 1) najprije, ona, smatra Hegel, poima državu kao jamstvo

${ }^{10}$ Iste primjedbe Hegel iznosi u svojim predavanjima o povijesti filozofije, gdje su izložene u okviru razmatranja Hobbesove političke filozofije (usp. Hegel, 1970: 341). U predavanjima o filozofiji prava iz 1824/1825. upućene su tradiciji modernog prirodnog prava u cjelini.

${ }^{11}$ Hegelova kritika ima za posljedicu odbacivanje ideje prirodnog stanja i ugovornog utemeljenja države, ali ne i modernog prirodnog prava u cjelini, odnosno njegovih najvažnijih principa. Već je iz navedenih Hegelovih iskaza vidljivo kako on svoju filozofiju prava smješta bliže prirodnom pravu nego pozitivnoj znanosti o državi, navodeći slobodu ili volju kao zajedničko ishodište svoje filozofijske pravne znanosti i prirodnopravnog učenja o državi. Činjenica da on ne polazi od prirodne volje kao "empirijske", nego, u skladu s vlastitim razlikovanjem dvaju značenja izraza "priroda", od pojma volje u kojemu su partikularna određenja već sjedinjena s općenitošću volje, ne znači, kako upozorava Riedel, "opoziv, nego zapravo izrazito zaoštravanje prirodnopravnog mišljenja. Jer time postaje pojedinac ne više kao takav, u svojoj prirodnosti, nego kao umno biće izlazište i predmet pravnog nauka" (Riedel, 1970: 35). Prirodnopravne teme u užem smislu Hegel razmatra u "apstraktnom pravu" (privatno vlasništvo, ugovor) i "moralnosti" (dobrobit i savjest), u kojim sferama je čovjek uspostavljen kao pravni i moralni subjekt. Nasuprot tome, pojam ćudorednosti on razvija iz “"etičkog' ustrojstva slobodnoga građanskog života, koje je konstitutivno za grčki svijet” (Ritter, 1974: 226), suprotstavljajući prirodnopravnoj ideji države Aristotelovo shvaćanje da "čovjek svoju prirodu može 'ozbiljiti' tek u ćudorednim institucijama" (Ottmann, 1982: 385). No stajalište ćudorednosti nije naprosto obnova Aristotelova učenja. Hegel opisuje specifično moderne institucije zajedničkog života, u kojima su integrirani fundamentalni principi "apstraktnog prava" i "moralnosti". Oni su "ukinuti” (u specifično Hegelovu smislu tog izraza) u ćudorednosti, što znači da su prevladane njihove jednostranosti, ali su sačuvana i dalje razvijena njihova bitna određenja. Ćudorednost sadrži i jamči "pravo individue na njenu posebnost" (FP, §154), koje predstavlja "prekretnicu i središte u razlici između starog vijeka i modernog vremena" (FP, §124). Hegelov odnos prema modernom prirodnom pravu može se, kako ističe N. Bobbio, shvatiti kao istovremena "razgradnja" $i$ "dovršenje": "Na paradoksalan je način Hegelova filozofija prava, koja se predstavlja kao negacija svih sustava prirodnog prava, istovremeno posljednji i najpotpuniji sustav prirodnog prava" (Bobbio, 1973: 291). 
i instrument zaštite te ostvarivanja privatnih interesa. Ta je primjedba iznesena već pri razmatranju ugovora u apstraktnom pravu: "Miješanje toga [ugovornog odnosa, nap. D. V.], kao i odnosa privatnog vlasništva uopće, u državni odnos proizvelo je najveće poremećaje u državnom pravu i zbiljnosti” (FP, §75). Tu primjedbu kasnije Hegel ponavlja u manje-više istom smislu u prvom paragrafu o državi (FP, §258); 2) ugovornom konstitucijom se država uspostavlja kao instanca formalne općosti koja kao izvanjska moć drži na okupu mnoštvo partikularnih interesa. Argumentacija o "izvanjskoj općosti” u Filozofiji prava iznesena je u vezi s Kantovim pravnim naukom (FP, §29), a u Povijesti filozofije usmjerena je protiv Hobbesa, kod kojega "opća volja ne znači volju svih pojedinaca, nego volju regenta koji, prema tome, nije odgovoran pojedincima, već je naprotiv usmjeren protiv te privatne volje" (PF, 341). Prema Hegelovu sudu "iz tog sasvim pravilnog shvaćanja" kod Hobbesa "proizlazi stanje apsolutne vladavine, stanje savršenog despotizma" (PF, 342). ${ }^{12}$ Naposlijetku, 3) ugovornom konstitucijom država je učinjena ovisnom o empirijskoj proizvoljnosti pojedinaca, čija zajednička partikularna volja samo slučajno iz sebe može dati umnu općenitu volju. Ta kritika cilja, naravno, na Rousseaua, čiju političku teoriju Hegel vidi ozbiljenom u Francuskoj revoluciji. ${ }^{13}$ Zajednički je međutim nedostatak svih ugovornih pristupa, neovisno o svim površinskim razlikama među njima, u tome što oni državu ne uspijevaju izvesti kao "umno" posredovanje “općosti” i "posebnosti”, nego su u njima opći interes i posebni interes ili apsolutno razdvojeni ili u konačnici postavljeni u nerazlučeno jedinstvo svođenjem "općenite volje" na puki zbroj partikularnih volja.

${ }^{12}$ Hegelov je sud o Hobbesu u cjelini ambivalentan. De cive i Levijatan smatra on djelima koja "sadrže više-manje zdrave misli o prirodi društva i vlade, koja su djelomično još u opticaju" (PF, 339), njegova su "shvaćanja površna, empirička; međutim razlozi i stavovi za njih jesu originalni, budući da su proizašli iz prirodne potrebe" (PF, 340). Hobbes je bio prvi koji je "pokušao državni savez, prirodu državne vlasti svesti na one principe koji se nalaze u nama samima, koje mi priznajemo kao vlastite principe" (ibid.). Osim toga, on jedini shvaća prirodno stanje "u njegovom pravom smislu, to nije prazno brbljanje o nekom stanju koje je po prirodi dobro, naprotiv, to je životinjsko stanje, stanje neslomljene vlastite volje", iz čega "Hobbes izvodi zaključak da 'čovjek mora izaći iz prirodnog stanja (e tali statu exeundum)'. To je točno. Prirodno stanje nije pravno; ono se mora prevazići” (PF, 341).

${ }^{13}$ Rousseauova je velika zasluga što je "volju postavio kao princip države. No time što je on volju shvaćao samo u određenom obliku pojedinačne volje (kao kasnije i Fichte), a opću volju ne kao ono po sebi i za sebe umno volje, nego samo kao ono zajedničko, što proizlazi iz ove pojedinačne volje kao svjesne: zato ujedinjenje pojedinaca u državi postaje ugovorom, koji im tako za temelj ima njihovu hotimičnost, mnjenje i proizvoljno, izričito pristajanje. (...) Došavši do vlasti, te su apstrakcije zbog toga proizvele, dakako, s jedne strane prvi, otkad znamo za ljudski rod, čudesni prizor da sustav jedne države započne sasvim ispočetka i od misli prevratom svega opstojećega i danoga (...) s druge strane, budući da su to samo bezidejne apstrakcije, one su taj pokušaj učinile najstrašnijim i najoštrijim događajem” (FP, §258). 
Ovdje izloženi sažetak Hegelovih objekcija ugovornoj konstituciji države ne smije nas međutim zavesti na stav da on jednoznačno i u cijelosti odbacuje ugovornu teoriju. Primjerenim mjestom njene realizacije on smatra, kako će se pokazati, sferu građanskog društva, kao moment unutarnje strukture države ili ideje prava. Koja sfera onda istodobno predstavlja unutarnju i zbiljsku mjeru kritike te teorije. Ali svejedno čini nužni moment opstanka pojma slobode u njenom samorazvoju prema svom punom ozbiljenju.

Hegelov stav o građanskom društvu kao mjestu ozbiljenja i afirmacije ideje društvenog ugovora, ali i mjestu koje otkriva neadekvatnost te ideje za teorijsko utemeljenje države posredovan je, kao što je rečeno, njegovim studijem klasične političke ekonomije, koja, baš kao i on, odbacuje ugovornu političku teoriju. Zajednički su im i mnogi razlozi tog odbacivanja, iako ne i argumenti, a pogotovo ne konačni ishod s obzirom na razumijevanje države kao pravno-političke i političkoekonomske zajednice. I u tom je pogledu najveći utjecaj na Hegela izvršio Adam Smith. ${ }^{14}$ No teren za Smithovo ekonomsko utemeljenje društva prirpremio je, kako pokazuje Strpić, već Hume, koji raščišćava s ugovornom političkom teorijom, osporavajući "historijsku realnost 'principa izvornog ugovora ili narodnog usuglašavanja" (Strpić, 2017: 115). ${ }^{15}$ Osnovu društva Hume vidi u trgovini, odnosno u njome omogućenom transferu vlasništva i njegovu uvećanju, a u prednostima koje iz toga nastaju za članove društva pronalazi, u skladu s common senseom, izvor njihove političke obveze i motiv susprezanja individualne samovolje poradi očuvanja društvenih institucija (ibid.: 117). Shvaćajući trgovinu kao proces koji se neprekidno odvija među članovima društva, Hume više ne traži princip konstitucije društva u njemu izvanjskoj moći, nego pokazuje da su njegovo "razlaganje i ponovno uspostavljanje dvije (...) tendencije koje su mu imanentne, a ne dva različita historijska stanja" (ibid.: 115).

Na terenu koji je tako pripremio Hume, Smith gradi svoj sistem političke ekonomije i razvija analizu modernoga građanskog ili "trgovinskog” društva. U njegovoj je osnovi "sklonost razmjeni" kao historizirano obilježje ljudske prirode vezano uz moderno društvo utemeljeno na podjeli rada koja je uzrok njegovog najvećeg bogatstva (Strpić, 2017: 120). Vezivno tkivo strukture tog društva je pak "kupovna moć”, kojom Smith, u samorazumijevanju, kako pokazuje Strpić, razbija kod Hob-

${ }^{14}$ Za usporedbu Smitha i Hegela vidi studiju L. Herzog, Inventing the Market - Hegel, Smith and Political Theory, koja razmatra odnos Smitha i Hegela s obzirom na pitanja odnosa pojedinca i zajednice, socijalne pravednosti, odnosa između različitih dimenzija slobode na tržištu i povijesnosti tržišta (Herzog, 2013: 11). Informativan pregled Smithova utjecaja na Hegela daju Henderson/Smith (1991). Za usporedbu Smithova i Hegelova ekonomskog nauka vidi Priddat, 1990: 22-36 i dalje.

15 O Humeovoj kritici društvenog ugovora vidi Murphy, 1978: 66-72. 
besa još prisutan amalgam prirodnih i instrumentalnih moći, shvaćajući "kupovnu moć" kao društvenu moć, odnosno kao osnovu svake druge moći u društvu i izjednačujući ju s razmjenskom vrijednošću (ibid.: 121). Polazeći od podjele rada, koja svakog čovjeka upućuje na rad drugih, Smith utvrđuje da se vrijednost robe za osobu koja ju posjeduje sastoji u " "količini rada koju joj ona omogućuje da kupi ili njome vlada" (ibid.), odnosno da se određuje prema količini rada koja je bila potrebna za proizvodnju druge robe s kojom se ta roba zamjenjuje. Već iz toga je vidljivo, kako upozorava Strpić, da je rad za Smitha više od pukog izvora vrijednosti. "Preko razmjenske vrijednosti koju utemeljuje", on je "nexus rerum, veza svih društvenih stvari” (ibid.: 122), što još očitijim postaje kasnije u Strpićevu razmatranju Smithove kategorije stocka kao za robnu proizvodnju tezauriranog rada, no to razmatranje ovdje ne možemo dalje slijediti. Ovdje međutim valja navesti dvije temeljne posljedice Smithove analize, koje proizlaze iz njegova diferenciranja u Hobbesa, prema Smithovu i Strpićevu shvaćanju, još nerazlučenih prirodnih i instrumentalnih individualnih moći. Prvo, za razliku od Hobbesovih individualnih moći, koje su uvijek defanzivne ili ofenzivne spram drugoga, pa je potrebna izvanjska moć koja će ih ograničiti ili držati na okupu, kupovna moć, koja je u temelju Smithova shvaćanja građanskog društva, gradi kooperativni karakter tog društva, jer već u sebi sadrži općenitost, kako pokazuje Smithova analiza razmjenske vrijednosti i rada (ibid.: 129). Drugim riječima, građansko društvo princip svoje konstitucije ima u sebi samome i reproducira se prema sebi imanentnim zakonitostima. Zahvaljujući tome, drugo, ono, kao središnja sfera državne cjeline ili commonwealtha, može iz sebe jasno izlučiti političku državu kao izvanjski okvir svog funkcioniranja (ibid.: 132), što nije pošlo za rukom ugovornoj tradiciji, koja, utemeljujući državnu cjelinu općim transferom moći od pojedinca k općoj osobi, ne uspijeva jasno razdvojiti društvenu od političke sfere državne zajednice (ibid.: 121). U ovom dvostrukom zaključku sadržano Strpićevo tumačenje Hobbesa u bitnome odgovara Hegelovu shvaćanju ugovorne tradicije, što se očituje u njegovu "otkriću" dvoznačnosti izraza "priroda čovjeka" u modernom prirodnom pravu i stavu da u ugovornoj teoriji inicirano razdvajanje države i društva biva revidirano izvođenjem općenite volje iz mnoštva empirijskih partikularnih volja pojedinaca (FP, §§182D, 258). ${ }^{16}$

Hegelovo razračunavanje s ugovornom teorijom uz pomoć političke ekonomije u velikoj je mjeri utjecalo na shvaćanje "građanskog društva" koje nalazimo u Filozofiji prava, kao i na artikulaciju odnosa te sfere s "političkom državom". Smithov utjecaj pritom je neposredno vidljiv u izvedbi "sustava potreba" kao ekonomske osnove građanskog društva, u kojoj središnje mjesto zauzima podjela rada (shvaćena i kao podjela u proizvodnom pogonu, ili potpodjela rada). Budući da

${ }^{16}$ Usp. također Riedel (1970: 39 i dalje), koji je prvi ponudio takvo tumačenje Hegelova razumijevanja odnosa države i građanskog društva u ugovornoj političkoj teoriji. 
čovjek u modernom društvu ne može zadovoljiti cjelokupni opseg svojih potreba neposredno vlastitim radom, on proizvodi za jednu "apstraktnu" društvenu potrebu, a sredstva za njegove ostale potrebe proizvod su rada drugih. Rad je tako temeljna općost u "sustavu potreba", koja "izvanjskim stvarima" daje vrijednost, čineći ih robama, odnosno prenoseći na stvari "važenje općenitosti”. Iz Hegelova izlaganja "sustava potreba" potrebno je naglasiti dvije stvari. Prvo, subjekt građanskog društva je čovjek kao biće potreba i rada ili "konkretnost predstave" i "tek je, dakle ovdje, i zapravo samo ovdje, riječ o čovjeku u tom smislu” (FP, §190). "Sustav potreba" u tom smislu "domovina je pojedinca" ili povijesno tlo realizacije apstraktne predodžbe o čovjeku do koje je došla ranija politička teorija (Strpić, 2017: 144). I drugo, pojedince tako posredstvom potreba i rada emancipirane od "sviju pretpostavki povijesno dobivenih životnih poredaka" (Ritter, 1989: 42), "sustav potreba" ne ostavlja u stanju izoliranosti, nego ih ponovo i uvijek iznova povezuje u "sustav međusobne ovisnosti" u pogledu osiguranja egzistencije, zadovoljenja potreba i ostvarivanja dobrobiti. Čini se, dakle, da time što prepoznaje različite oblike općenitosti imanentne građanskom društvu (potreba, rad, vrijednost, novac), Hegel na tragu političke ekonomije (kojoj je, podsjetimo, odao priznanje jer je otkrila "zakonitosti" u beskonačnome mnoštvu pojedinačnosti građanskog društva) smatra kako ono ima princip konstitucije u sebi samom, koji mu omogućuje da funkcionira u skladu s vlastitim zakonitostima.

No takav zaključak bio bi preuranjen i ne u potpunosti točan. Naime, općenitost, iako je građanskom društvu imanentna, istovremeno mu je izvanjska. Ili, preciznije, izvanjska je njegovim članovima. Općenitost, drugačije rečeno, u svim njenim pojavnim oblicima, neovisna je o stvarnom cilju njihova djelovanja i predstavlja oblik koji njihova međusobna povezanost mora zadobiti (potreba uopće, apstraktni rad, proizvod kao roba) da bi oni mogli zadovoljiti svoje privatne interese. A kada se uspostavlja u pojavnom obliku eventualne ravnoteže ili harmonije privatnih interesa (ako se uopće kao takva uspostavlja sama od sebe), onda je ona, Hirschmanovim riječima, "neintendirana posljedica djelovanja" (Hirschman, 1991: 35-36), odnosno nastaje "iza leđa" pojedinaca okrenutih zadovoljenju privatnih svrha. Stoga Hegel ističe da je ono ćudoredno u građanskom društvu izgubljeno u svoje ekstreme i da su se posebnost i općenitost raspali, a opet su uzajamno povezani i uvjetovani (FP, §184D). Tek na taj način građansko društvo po Hegelovu sudu predstavlja povijesnu istinu teorija društvenog ugovora: kao sfera u kojoj ona izvanjska općenitost ugovornih političkih teorija postaje unutrašnja, a opet ostaje samo formalna i na izvanjski način povezuje sjedinjene pojedince. Koji zbog toga i nisu istinski sjedinjeni, nego stoje samo u zajedništvu. U prvom paragrafu o građanskom društvu to Hegel odmah jasno daje do znanja, nakon što je izveo odnos između njegova dva principa, ističući: “Ako se država predstavlja kao jedinstvo različitih 
osoba, jedinstvo koje je samo zajedništvo, onda se time misli samo na određenje građanskog društva. Mnogi od novih učitelja državnog prava ne mogu to dovesti ni do kakvog drugog nazora o državi” (FP, §182D).

Ta kritika pogađa i ideju države modernog prirodnog prava i model države/ društva klasične političke ekonomije. Ali ne u jednakoj mjeri. Povezivanje u građanskom ili "trgovinskom društvu", koje opisuje politička ekonomija (kao i Hegel), iako izvanjsko, potpunije je nego ono u državi konstituiranoj društvenim ugovorom. Općenitošću koja je imanentna građanskom društvu, zasnovanom na tržišnoj ekonomiji, prevladan je "atomizam" ugovornog shvaćanja države. O tome svjedoči, kako je upozorio M. Giusti, i Hegelova upotreba kategorija različitih logičkih razina pri razmatranju ideja države te dvije tradicije. U kritici ugovornog nauka, čiji je cilj pokazati “njegovu nesposobnost izvođenja političkog sjedinjenja ('općenitosti') iz prethodne izoliranosti individua", Hegel se služi logičkim kategorijama bitka. Odnosno, on "interpretira suprotnost pojedinačnosti i općosti kao formu refleksije, koja nije svjesna uzajamne determiniranosti relata" (Giusti, 1987: 276). ${ }^{17}$ Pri opisu građanskog društva on pak rabi logičke kategorije bîti; "nedvojbeno su i tamo ishodište partikularnost proizvoljnosti i potreba, ali su one razmotrene u njihovoj nužnoj svezi s implicitno priznatim društvenim institucijama proizvodnje i prava" (ibid.). ${ }^{18}$

Iako je tako "povezanost" građanskog društva na višoj logičkoj razini od one u ugovornom modelu države, ona, u skladu s određenjima logičkog stupnja bîti, pokazuje "razdvajanje općeg i posebnog, forme i sadržaja, koji su tako $u$ odnosu, a da nisu sjedinjeni” (Arthur, 1988: 23). Imanentna općenitost građanskog društva, kako je pokazano, ostaje izvanjska njegovim članovima, jer je samo sredstvo ili nenamjeravani ishod njihove težnje za ostvarivanjem vlastitih posebnih interesa. Zbog toga, kako je znano, Hegel poima političku državu kao najvišu sferu države kao (ćudoredne) cjeline, u kojoj sferi treba biti na djelu samosvjesna općenitost (u razlici spram građanskog društva). Time on međutim $u$ istom koraku prevladava ono što vidi kao deficit ugovornih pristupa, ali i temeljnu manjkavost pojma države klasične političke ekonomije. Kritizirajući ovu posljednju ovaj put sa stajališta ugovorne političke teorije (premda ne sasvim osviješteno). Za razliku od ugovornih modela, u kojima je umjetno tijelo pravno-političkog jedinstva oživljeno djelova-

17 Tako je ugovorna teorija države tematizirana i u nauku o bitku "Znanosti logike" u Enciklopediji filozofijskih znanosti: "Još važnijim nego u fizičkom, postao je atomistički nazor u političkom pogledu. Po njemu je pojedinčeva volja, kao takva, princip države; ono što atrahira jest partikularitet potrebā, nagnuća, a ono opće, sama država, jest vanjski odnos ugovora” (EFZ, §98P). ${ }^{18}$ Kako ističe Schmidt, "činjenica da je bilo moguće imati znanosti političke ekonomije - premda one za Hegela ostaju na razini razuma - znači da je građansko društvo, kao i svijest, moglo generirati vlastite kategorije" (Schmidt, 1981: 491). 
njem suverene moći, ekonomski utemeljeno građansko društvo određuje Hegel već u prvoj jenskoj Realnoj filozofiji kao "život mrtvoga”, koji se kreće sam od sebe, i čije je kretanje slijepo i elementarno (JR I, 334). A odnosi među pojedincima - članovima građanskog društva - koji se odvijaju preko stvari i na način stvari, konstituiraju se, primjećuje Hegel u Sustavu ćudorednosti, u njima stranu moć, kojoj oni ništa ne mogu (SĆ, 63). Uzimajući sve to u obzir, Strpić s pravom upozorava da postulirani čovjek u liku bourgeois nije realiziran kao subjekt građanskog društva, precizno prepoznajući da "čovjek" kod Hegela kao "izvršitelj" apstraktnog rada, u svom parcijalnom djelovanju, ima "snagu", a (još) ne "moć" (Strpić, 2017: 145). No Hegel je također, kad je riječ o građanskom društvu kao cjelini, puno manje od Smitha sklon optimizmu u pogledu samoregulatornog karaktera njegovih tržišnih mehanizama, odnosno predodžbi o "ravnoteži međusobno sukobljenih interesa" kao ishodu autohtonih ekonomskih zakonitosti građanskog društva. Pa iako smatra kako se "ispravan odnos, doduše, sam od sebe uspostavlja u cjelini", jednako ističe da je potrebno "reguliranje, koje stoji iznad (...) i koje se poduzima svjesno" (FP, §236). Najjasnije to dolazi do izraza u tendenciji građanskog društva da nagomilava bogatstvo u rukama jedne klase i produbljuje nuždu i zavisnost one klase koja je vezana uz upojedinjavanje i ograničenost posebnog rada, čime se pokazuje da ono "pri preobilju bogatstava (...) nije dovoljno bogato (...) da otkloni prekomjernost siromaštva" (FP, §245). Stoga Hegel već u građansko društvo smješta "upravne" institucije države, koje trebaju izvanjski osigurati predominaciju "općeg interesa" u "sustavu potreba" nasuprot njemu imanentnim destruktivnim tendencijama. Tim je institucijama stoga dopušten širi raspon regulacije i dalekosežniji intervencionistički zahvat nego je to slučaj u klasičnom liberalnom polit-ekonomskom modelu kad je riječ o odnosu države prema ekonomiji.

Prva od tih institucija je policija, čija je uloga "opća predostrožnost i nadzor" nad tržištem, odnosno "svjesno reguliranje" njegovih procesa (usp. FP, §§235, 236). ${ }^{19}$ Neke od funkcija policije (osiguranje javnih dobara poput obrazovanja, zdravstvenih usluga, javne infrastrukture, kontrola kvalitete proizvoda, zaštita potrošača) uklapaju se, ili se mogu uklopiti u model države i društva klasičnog eko-

${ }^{19}$ U Hegelovu shvaćanju policije najizravnije se očituje utjecaj J. Steuarta i njegova zagovaranja državnog nadzora nad ekonomijom. Doduše, Steuart ne rabi sam izraz u svojim Istraživanjima, djelomično jer je on bio stran britanskoj tradiciji, a djelomično jer se smatrao nespojivim s britanskom slobodom (Neocleous, 1998: 51). No izraz je itekako prisutan u Steuartovu mišljenju srodnoj tradiciji njemačkog kameralizma, čiji je dio bila "znanost o policiji" (ibid.: 45). U kameralizmu, za koji ekonomija još nije autonomno područje ljudskog djelovanja, nego integralni dio državne politike, neposredno povezan s pitanjem suverenosti i državne moći, glavna zadaća policije bila je "razvoj trgovine i proizvodnja bogatstva" (ibid.: 46). Kod Hegela, doduše, policija više nema tu ulogu, ali "nema sumnje da su njemu bili poznati kameralizam i znanost o policiji" (ibid.). Za Hegelovo shvaćanje uloge policije vidi i Herzog, 2015. 
nomskog liberalizma, ali taj model Hegel nadilazi kada policiji dodjeljuje nadležnost za ekonomsku politiku koja podrazumijeva intervenciju u tržišne procese. Jedna od njezinih zadaća je naime i otklanjanje onih tržišnih poremećaja koji tendencijski uzrokuju nezaposlenost i povećavaju nejednakost u pogledu raspodjele bogatstva. U Filozofiji prava, doduše, nisu razmotrene mjere kojima policija izvršava svoju ekonomsko-političku ulogu, ali Hegel ističe kako su "nužni opća predostrožnost i rukovođenje uslijed ovisnosti velikih industrijskih grana o izvanjskim okolnostima i dalekim kombinacijama, što ih u njihovoj povezanosti ne mogu sagledati individue koje su upućene i vezane uz onu sferu" (FP, §236). ${ }^{20}$ Jednako je u tom pogledu važna uloga korporacija, u koje su organizirani oni članovi građanskog društva čiji su prihodi ovisni isključivo o tržištu (tzv. "zanatlije"). Korporacija za njih preuzima skrb u slučajevima kada oni zbog zakazivanja tržišta ne mogu svojim radom osigurati vlastitu egzistenciju. Ona to čini dijelom izravno, redistribucijom ukupnog dohotka članova korporacija, a dijelom neizravno, stvaranjem zaposlenja unutarkorporativnim alociranjem poslova za kojima postoji tržišna potražnja i usavršavanjem radnih sposobnosti svojih članova (usp. Priddat, 1990: 196, 201, 212). Na taj način ona osigurava stabilan i predvidiv okvir privrednog djelovanja, oslobađajući pojedinca od "slijepe ovisnosti" o "slučajnostima" tržišnih procesa. Osim toga, ona predstavlja protutežu "apstraktnosti” čovjekova položaja u "sustavu potreba", u kojemu je on reduciran na vlastiti sebični interes i s drugima povezan samo putem "nesvjesne nužnosti" podjele i specijalizacije rada te tržišne razmjene. Kao član korporacije pojedinac u građanskom društvu prvi puta pripada nekoj organiziranoj cjelini, svjesno djelujući u korist njena "zajedničkog interesa", u odnosu na koji se uči susprezati svoje posebne interese. U tome leži posebna ćudoredna vrijednost korporacije, pa Hegel napominje kako se u njoj ono ćudoredno "kao ono imanentno vraća u građansko društvo" (FP, §249). ${ }^{21}$

${ }^{20}$ Neki interpreti smatraju kako policija u Filozofiji prava nema privredno-političke kompetencije. "Privredna politika ograničava se na prevenciju i zaštitu (...); otuda njegov oprez i sustavna neodređenost u pitanjima realnih kompetencija policije" (Priddat, 1990: 114). Čini se međutim kako je razlog nerazmatranja konkretnih privredno-političkih mjera Hegelovo uvjerenje da se one ne mogu unaprijed odrediti jer ovise o promjenjivim okolnostima: "Ovdje se ne mogu postaviti nikakva čvrsta određenja niti povući apsolutne granice. Sve je ovdje osobno; javlja se subjektivno mnijenje, a duh uređenja, opasnosti vremena, trebaju saopćiti bliže okolnosti" (FP, §234D). Iako sasvim općenito, nadležnost policije za privrednu politiku nedvojbeno utvrđuje, kako je pokazano, \$236 Filozofije prava. Na tu nadležnost upućuje već Hegelova upotreba formulacija "nadzor i predostrožnost javne moći" (FP, §235), "reguliranje (...) koje se poduzima svjesno" (FP, §236), “opća predostrožnost i rukovođenje” (ibid.).

${ }^{21}$ Ulogu korporacije Priddat smatra središnjom u Hegelovoj viziji ekonomije. Hegel po njegovu sudu razvija koncepciju korporativnog ustrojstva privrede, kao rješenje "dileme između tržišne i državne privrede" (Priddat, 1990: 116). U cjelini međutim Hegel, prema Priddatu, ne provodi imanentnu ekonomsku analizu, nego ekonomske fenomene procjenjuje i testira na pravnim i ću- 
No čak ni takvo građansko društvo, koje u sebi već obuhvaća mnoge "nepolitičke" državne funkcije, za Hegela nije, kako je već rečeno, najviši stupanj ozbiljenja slobode pojedinca u državi kao umno raščlanjenom ćudorednom totalitetu, nego je to politička država. Ova pak ne može biti uspostavljena ugovorno, jer bi time, iz razloga koji su prethodno razmotreni, bilo dobiveno samo stajalište građanskog društva. Stoga Hegel još jednom iznosi svoje glavne argumente protiv ugovorne političke teorije na početku razmatranja političke države (FP, §258). Ona međutim nije ni izvanjski okvir funkcioniranja ekonomski samoreproducirajućega građanskog društva, kao u klasičnoj polit-ekonomskoj liberalnoj teoriji, nego je, nasuprot obama tim shvaćanjima, u njoj, ističe Hegel, "Ujedinjenje kao takvo sâmo istinski sadržaj i svrha, pa je određenje individua da žive općim životom; njihovo dalje posebno zadovoljavanje, djelatnost, način držanja ima taj supstancijalitet i opću važnost kao svoju polaznu točku i rezultat" (FP, §258). Na taj način Hegel na stajalištu političke države rehabilitira antičko shvaćanje prema kojemu politički život predstavlja ozbiljenje čovjekove prirode, u jasnoj i izričitoj opreci spram svakog instrumentalnog određenja države koje njezinu svrhu stavlja u zaštitu života ili vlasništva, odnosno nastojanja da se ona izvede iz drugih oblika zajedništva. Ali za naše razmatranje neposredno je važnije da građansko društvo, kako je izloženo u Filozofiji prava, premda sadrži imanentne ekonomske zakonitosti koje mu daju relativnu sposobnost samoreprodukcije, nema "centar gravitacije" u sebi samom, nego u političkoj državi. U zbiljnosti je, ističe Hegel, "država ono prvo", unutar kojega se obitelj i građansko društvo tek izgrađuju do svoje samostalnosti, pa ona za njih ostaje izvanjska nužnost i viša moć, ali predstavlja i njihovu imanentnu svrhu (FP, §§256, 261). Održanje "sustava potreba" i uspostavljanje njemu imanentne općosti u krajnjoj instanci ovisi o institucijama koje nemaju porijeklo u tržišnim procesima, nego u "općenitosti” političke države. Policija i korporacije organi su preko kojih politička država provodi "svjesno reguliranje" sustava potreba i osigurava "ćudorednost" ishoda tr-

dorednim normativnim principima. "Uvijek treba imati na umu da on ne piše ekonomiju, nego filozofiju prava, koja istražuje pravne uvjete svake ekonomije" (ibid.: 54). U središtu je Hegelova pravno-filozofijskog pristupa ekonomiji pritom "pravo na rad", ili na prihod od vlastitog rada, kao izvor čovjekova dostojanstva (ibid.: 39). "Tome pravu Hegel daje (prirodnom pravu odgovarajuće) utemeljenje u 'pravu na život', koje u tom obliku predstavlja najopćenitije pravo čovjeka. Pravo na rad postavljeno je pred ekonomiju kao ćudoredno-opći zahtjev" (ibid.: 54). Realizacija tog prava zadaća je prvenstveno korporacija. "Korporacije su institucionalizirano rješenje problema stvaranja i osiguranja rada: ne državna politika zapošljavanja, nego korporativni poredak tržišne privrede treba spriječiti negativne posljedice industrijalizacije" (ibid.: 199). Treba međutim istaknuti da Priddat Hegelu pristupa iz klasično-liberalne ekonomske perspektive, "mjereći” Hegelova ekonomska razmatranja Smithovim pojmom političke ekonomije, pri čemu on ipak dopušta mogućnost korporativne samoupravne privrede kao ekonomskog modela koji je "potpuno liberalan, ali ne-individualistički" (ibid.: 202). 
žišnih procesa. ${ }^{22}$ Uvažavajući i preuzimajući nalaze klasične političke ekonomije, Hegel se tako na stanovit način vraća političkom utemeljenju društva ugovorne političke teorije. Izmještanje principa konstitucije građanskog društva u političku državu u Filozofiji prava pokazuje s jedne strane kako je politička država kao instanca “opće suverene moći" uvjet mogućnosti postojanja građanskog društva i odvijanja onih procesa kojima se uspostavlja njemu imanentna općenitost. Ali s druge strane ono i upućuje na političku državu kao višu sferu ozbiljenja čovjekove slobode. Građanskom društvu je priznata relativna samostalnost, kao jednom određenju pojma slobode, ali tek kao političko biće, životom i djelovanjem u svjesnoj zajednici s drugima, čovjek dospijeva do svoje istinske slobode u sferi objektivnog duha.

\section{LITERATURA}

Arthur, Christopher J. 1988. Hegel's Theory of Value, u: Williams, Michael (ur.): Value, Social Form and the State. Macmillan Press. London: 21-41.

Bobbio, Norberto. 1973. Hegel und die Naturrechtslehre, u: Fetscher, Iring (ur.): Hegel in der Sicht der neueren Forschung. Wissenschaftliche Buchgesellschaft. Darmstadt: 291-321.

Chamley, Paul. 1963. Économie politique et philosophie chez Steuart et Hegel. Dalloz. Pariz.

Dickey, Laurence. 1987. Hegel - Religion, Economics, and the Politics of Spirit, 17701807. Cambridge University Press. Cambridge.

Giusti, Miguel. 1987. Hegels Kritik der modernen Welt - Über die Auseinandersetzung mit den geschichtlichen und systematischen Grundlagen der praktischen Philosophie. Könighausen-Neumann. Würzburg.

Göhler, Gerhard. 1974. Dialektik und Politik in Hegels frühen politischen Systemen. Kommentar und Analyse, u: Hegel, Georg Wilhelm Friedrich, Frühe politische Systeme. Verlag Ullstein GmbH. Frankfurt/M - Berlin - Wien: 337-610.

Göhler, Gerhard. 1976. Dijalektika i politika u Sustavu ćudorednosti, u: Hegel, Georg Wilhelm Friedrich, Sustav ćudorednosti. Studentski centar Sveučilišta u Zagrebu. Zagreb: 75-142.

22 Policija nije samoupravna instanca građanskog društva. O konkretnim ciljevima i dometima ekonomskog (i drugog) nadzora i regulacije odlučuje "upravna vlast” ili vlada (FP, §287). Isto tako korporacije nisu u potpunosti dobrovoljne asocijacije građana, jer svaki član "zanatlijskog staleža" ima obavezu pripadati nekoj korporaciji, koja, pored toga, mora biti podvrgnuta državnom nadzoru, "jer bi inače okoštala, bila bi u sebe zatvorena, potonula bi u bijedno esnafstvo" (FP, §255; o potrebi državnog nadzora nad korporacijama vidi i FP, §§288, 289 i 290). 
Hegel, Georg Wilhelm Friedrich. 1969. Enzyklopädie der philosophischen Wissenschaften im Grundrisse (1830). Felix Meiner Verlag. Hamburg.

Hegel, Georg Wilhelm Friedrich. 1969. Jenaer Realphilosophie - Vorlesungsmanuskripte zur Philosophie der Natur und des Geistes von 1805-1806. Felix Meiner Verlag. Hamburg.

Hegel, Georg Wilhelm Friedrich. 1970. Istorija filozofije 3. Kultura. Beograd.

Hegel, Georg Wilhelm Friedrich. 1974. Anhang zur Jenaer Realphilosophie. Ausarbeitungen zur Geistesphilosophie von 1803/04, u: Frühe politische Systeme. Verlag Ullstein GmbH. Frankfurt/M - Berlin - Wien: 291-335. (JR I)

Hegel, Georg Wilhelm Friedrich. 1974. Philosophie des Rechts nach der Vorlesungsnachschrift K. G. v. Griesheims 1824/25, u: Hegel, Georg Wilhelm Friedrich. Vorlesungen über Rechtsphilosophie 1818-1831. Fromman-Holzboog. Stuttgart-Bad Cannstatt. (PR 1824/1825)

Hegel, Georg Wilhelm Friedrich. 1975. Jenaer Systementwürfe I. Felix Meiner Verlag. Hamburg.

Hegel, Georg Wilhelm Friedrich. 1976. Sustav ćudorednosti. Studentski centar Sveučilišta u Zagrebu. Zagreb. (SĆ)

Hegel, Georg Wilhelm Friedrich. 1983. Jenski spisi 1801-1807. "Veselin Masleša”-Svjetlost. Sarajevo. (JS)

Hegel, Georg Wilhelm Friedrich. 1986. Grundlinien der Philosophie des Rechts. Suhrkamp. Frankfurt am Main.

Hegel, Georg Wilhelm Friedrich. 1986. Jenaer Schriften 1801-1807. Suhrkamp. Frankfurt am Main.

Hegel, Georg Wilhelm Friedrich. 1987. Enciklopedija filozofijskih znanosti. "Veselin Masleša". Sarajevo. (EFZ)

Hegel, Georg Wilhelm Friedrich. 1989. Osnovne crte filozofije prava. "Veselin Masleša"Svjetlost. Sarajevo. (FP)

Hegel, Georg Wilhelm Friedrich. 2002. System der Sittlichkeit [Critik des Fichteschen Naturrechts]. Felix Meiner Verlag. Hamburg.

Herzog, Lisa. 2013. Inventing the Market - Smith, Hegel and Political Theory. Oxford University Press. Oxford.

Herzog, Lisa. 2015. Two Ways of "Taming" the Market: Why Hegel Needs the Police and the Corporations, u: Buchwalter, Andrew (ur.): Hegel and Capitalism. State University of New York. Albany: 147-162.

Hirschman, Albert O. 1991. The Rhetoric of Reaction. Perversity, Futility, Jeopardy. The Belknap Press of Harvard University Press. Cambridge, Massachusetts and London, England.

Hont, Istvan. 2010. Jealousy of Trade. International Competition and the Nation-State in Historical Perspective. The Belknap Press of Harvard University Press. Cambridge, Massachusetts and London, England. 
Hont, Istvan. 2015. Politics in Commercial Society - Jean-Jacques Rousseau and Adam Smith. Harvard University Press. Cambridge, Massachusetts and London, England.

Ilting, Karl-Heinz. 1974. Hegels Auseinandersetzung mit der aristotelischen Politik, u: Hegel, Georg Wilhelm Friedrich, Frühe politische Systeme. Verlag Ullstein GmbH. Frankfurt/M - Berlin - Wien: 759-785.

Kapossy, Béla/Sonenscher, Michael. 2015. Editors' Introduction, u: Hont, Istvan, Politics in Commercial Society - Jean-Jacques Rousseau and Adam Smith. Harvard University Press. Cambridge, Massachusetts and London, England: ix-xx.

Murphy, Jeffrie G. 1978. Hume and Kant on the Social Contract. Philosophical Studies: An International Journal for Philosophy in the Analytic Tradition (33), 1: 65-79.

Neocleous, Mark. 1998. Policing the System of Needs: Hegel, Political Economy, and the Police of the Market. History of European Ideas (24), 1: 43-58.

Ottmann, Henning. 1982. Hegelsche Logik und Rechtsphilosophie. Unzulängliche Bemerkungen zu einem ungelösten Problem, u: Henrich, Dieter/Horstmann, Rolf-Peter (ur.), Hegels Philosophie des Rechts - Die Theorie der Rechtsformen und ihre Logik. Klett-Cotta. Stuttgart: 382-392.

Plant, Raymond. 1977. Hegel and Political Economy. New Left Review 103: 79-92; 104: 103-113.

Priddat, Birger P. 1990. Hegel als Ökonom. Duncker\&Humblot. Berlin.

Riedel, Manfred. 1970. Bürgerliche Gesellschaft und Staat bei Hegel. Luchterland Verlag. Neuwied i Berlin.

Riedel, Manfred. 1982. Zwischen Tradition und Revolution - Studien zu Hegels Rechtsphilosophie. Klett-Cotta. Stuttgart.

Ritter, Joachim. 1974. Moralität und Sittlichkeit. Zu Hegels Auseinandersetzung mit der Kantischen Ethik, u: Riedel, Manfred (ur.), Materialen zu Hegels Rechtsphilosophie. Suhrkamp. Frankfurt am Main: 217-244.

Ritter, Joachim. 1989. Hegel i francuska revolucija. "Veselin Masleša"-Svjetlost. Sarajevo.

Rosenkranz, Karl. 1844. G. W. F. Hegels Leben. Duncker und Humblot. Berlin.

Schmidt, James. 1981. A "Paideia" for the 'Bürger als Bourgeois': The Concept of 'Civil Society' in Hegel's Political Thought. History of Political Thought (2), 3: 469-493.

Siep, Ludwig. 2014. Anerkennung als Prinzip der praktischen Philosophie - Untersuchungen zu Hegel Jenaer Philosophie des Geistes. Felix Meiner Verlag. Hamburg.

Smith, Adam. 2007. Istraživanje prirode i uzroka bogatstva naroda. Masmedia. Zagreb.

Strauss, Leo. 1988. What is Political Philosophy and Other Studies. The University of Chicago Press. Chicago i London.

Strauss, Leo/Cropsey, Joseph. 2006. Povijest političke filozofije. Golden Marketing-Tehnička knjiga. Zagreb. 
Strpić, Dag. 2017. Robna proizvodnja i udruženi rad u Marxovoj kritici političke ekonomije. Disput. Zagreb.

Vujeva, Domagoj. 2009. Prilog genealogiji Hegelova poimanja građanskog društva (Članak o prirodnom pravu, 1802.). Politička misao (46), 3: 157-173.

Vujeva, Domagoj. 2015. Država i demokracija. Građansko društvo i politička država u Filozofiji prava. Disput. Zagreb.

Waszek, Norbert. 1988. The Scottish Enlightenment and Hegel's Account of 'Civil Society'. Kluwer Academic Publishers. Dordrecht/Boston/London.

Weisser-Lohmann, Elisabeth. 2011. Rechtsphilosophie als praktische Philosophie. Hegels Grundlinien der Philosophie des Rechts und die Grundlegung der praktischen Philosophie. Wilhelm Fink. München.

\title{
Domagoj Vujeva
}

\section{POLITICAL ECONOMY AND THE CRITIQUE OF SOCIAL CONTRACT THEORY IN HEGEL'S PHILOSOPHY OF RIGHT}

\begin{abstract}
Summary
The author deals with Hegel's reception of political economy in the Philosophy of Right, showing that reception to be decisive for the development of Hegel's legal and political philosophy and its mature form, but also for his understanding of the modern natural law tradition and the theory of social contract. Relying on the findings of Dag Strpić, the author argues that Hegel considered "civil society" to be the place of realization of the contractual idea of the state. The "laws" immanent to modern market economy, which were "discovered" by political economy, make in Hegel's view contractual constitution of the state superfluous and provide at the same time the internal measure for the critique of the contractual theory. This, however, does not mean that Hegel accepts the social model of classical political economy, nor its understanding of the relation between the state and society. He questions its central assumption on the self-regulatory capacity of the market, for which reason he finds necessary the regulation of the market by the state. In the final analysis, as it is shown, the "universality" of civil society is grounded in the "universality" of the political state, which is a higher level of actualization of human freedom than civil society.
\end{abstract}

Keywords: Hegel, Political Economy, Strpić, Social Contract

Domagoj Vujeva, docent na Odsjeku za političku i socijalnu teoriju Fakulteta političkih znanosti Sveučilišta u Zagrebu.

Kontakt: Domagoj Vujeva, Fakultet političkih znanosti, Ivana Lepušića 6, 10000 Zagreb, Hrvatska. E-mail: domagoj_vujeva@yahoo.com 